\section{Combining Ability and Heterosis for Capsaicinoids in Capsicum pubescens}

\author{
Yayeh Zewdie ${ }^{1}$ and Paul W. Bosland ${ }^{2}$ \\ Department of Agronomy and Horticulture, New Mexico State University, Las \\ Cruces, NM 88003
}

\section{Robert Steiner ${ }^{3}$ \\ University Statistics Center, New Mexico State University, Las Cruces, NM 88003}

\begin{abstract}
Additional index words. chile, general combining ability, pepper, pungency, specific combining ability
\end{abstract}

\begin{abstract}
The inheritance of capsaicinoid content was studied in five Capsicum pubescens Ruiz \& Pav. genotypes using diallel analysis. General combining ability and specific combining ability effects were significant for all capsaicinoids studied, indicating additive and nonadditive gene actions are present. The association of high capsaicinoid contents with high positive general combining ability of the parents also indicates the predominance of additive gene action in capsaicinoid inheritance. Because of the predominant additive gene effect, recurrent selection would be a good breeding method to increase capsaicinoid level in the population studied. Heterosis was observed in hybrids for some of the capsaicinoids, suggesting that $F_{1}$ hybrids could also be used to increase capsaicinoid content.
\end{abstract}

Chile pepper (Capsicum sp.) is valued in the world market for its pungency, color, and aroma. Pungency is caused by the presence of alkaloid compounds known as capsaicinoids (Suzuki and Iwai, 1984). Recent reports show that more than 20 capsaicinoids are found in chiles (Bosland and Votava, 1999).

Krajewska and Powers (1988) reported that humans perceive pungency of each capsaicinoid differently at low concentrations. Capsaicin, dihydrocapsaicin, and homodihydrocapsaicin cause a very irritating sensation in contrast to nordihydrocapsaicin that causes the least irritating sensation. These marked differences in the perception of the capsaicinoids signify the importance of studying each capsaicinoid separately. As suggested earlier (Bosland, 1993), different combinations of capsaicinoids could produce the different pungency characteristics of individual chile varieties, therefore, the capsaicinoid profile may have to be manipulated genetically to fit specific uses.

Genetic manipulation would be possible if the inheritance of the individual capsaicinoids are known. Plants of Capsicum pubescens, a domesticated species of chile, contain a relatively greater number of individual capsaicinoids and show more diversity in capsaicinoid profiles than any other Capsicum species studied (Collins and Bosland, 1994; Torabi, 1997). Because of this phenomenon, $C$. pubescens is

Received for publication 15 Sept. 2000. Accepted for publication 5 May 2001. A contribution of New Mexico State Univ. Agricultural Experiment Station, Las Cruces.

${ }^{1}$ Postdoctoral Fellow. E-mail address: ytarekeg @nmsu.edu

${ }^{2}$ Professor. E-mail address: pbosland@nmsu.edu

${ }^{3}$ Associate Professor. E-mail address:rsteiner@ nmsu.edu useful to study the inheritance of capsaicinoids. Therefore, this research was undertaken to determine the inheritance of the individual capsaicinoids based on general combining ability and specific combining ability.

\section{Materials and Methods}

Plant material. The five parents: NMCA80004, NMCA80058, NMCA80065 (low capsaicinoid parents); and NMCA80049, NMCA80062 (high capsaicinoid parents) are C. pubescens accessions and were mated in a diallel design including reciprocals to assess combining ability and cytoplasmic effect. All two generations by self-pollination. Plants of the parents were evaluated to confirm the capsaicinoid levels and to test for uniformity of the capsaicinoid profile of each line before hybridization.

Greenhouse experiment. C. pubescens is adapted to a relatively cool environment (Bosland, 1996) and grows poorly in the field at Las Cruces, N.M. Therefore, all C. pubescens plants were grown in a climate-controlled greenhouse at the Fabian Garcia Science Center, Las Cruces, N.M. The average daily maximum and minimum temperature of the greenhouse were $29^{\circ} \mathrm{C}$, and $18^{\circ} \mathrm{C}$, respectively. In 1997 , all parents and the $\mathrm{F}_{1}$ generations were evaluated in a randomized complete block design with four replications. Twelve seedlings of each generation (3 per pot) were transplanted to white plastic pots $\left(4560 \mathrm{~cm}^{3}\right.$ volume of growing medium) four weeks after sowing. Each pot was considered an experimental unit. The growing medium was a mixture of 1 peat moss: 1 silica sand : 1 loamy sand (by volume). At transplanting and again at flowering, $36 \mathrm{~g}$ of slow-release fertilizer (Osmocote ${ }^{\circledR} 14 \mathrm{~N}-4.2 \mathrm{P}-11.6 \mathrm{~K}$; Scott's-Sierra parents were maintained in the greenhouse for
Horticultural Products, Marysville, Ohio) was topdressed to each pot. Plants were watered twice a day to maintain optimum growth. Mature, ripe, succulent fruits were harvested from the first four node positions and then bulked per plant for analysis.

Laboratory Analysis. Capsaicinoids were separated and quantified by high-performance liquid chromatography (HPLC) following the "long run" method described by Collins et al. (1995). The capsaicinoid content was expressed in $\mathrm{mg} \cdot \mathrm{kg}^{-1}$. The capsaicinoids detected and measured were nornornordihydrocapsaicin (3-ND), nornordihydrocapsaicin (2-ND), nordihydrocapsaicin (NDH), capsaicin (CAP), dihydrocapsaicin (DH), isomer of dihydrocapsaicin (ISO), and homodihydrocapsaicin (HD). The sum of these capsaicinoids, i.e., total capsaicinoid content (CAPSD), was also evaluated.

Data analyses. Data on the capsaicinoid contents (i.e., mean of three plants per replication) for the $5 \times 5$ complete diallel crosses $(25$ treatments) were analyzed by the Griffing (1956) method I, model I, using a microcomputer program designed for diallel analysis (Burow and Coors, 1994). Because data were analyzed according to a fixed model, estimation of components of variance was not appropriate. Furthermore, estimation of effects [general combining ability (GCA) and specific combining ability (SCA) effects] are more informative than components of variance for the model I analysis (Halluar and Miranda, 1981). Duncan's new multiple range test (mean separation) was performed using SAS program (SAS Institute, Cary, N.C.). The parents vs. crosses was tested for significance by using contrast statement of SAS with one degree of freedom (SAS Institute, 1999). The parents vs. crosses comparison is a test for heterosis (average heterosis) (Halluar and Miranda, 1981). For practical reasons, high parent heterosis was also calculated using the following formula and discussed: High parent heterosis $=\left\{\left[\left(\mathrm{F}_{1}-\mathrm{HP}\right) / \mathrm{HP}\right]^{*} 100\right\}$; where HP $=$ high parent mean.

\section{Results}

Highly significant genotypic differences were observed for the capsaicinoids (Table 1). The contributions of general combining ability and specific combining ability to genotypic variation were significant at a $1 \%$ level for all capsaicinoids. Except for the isomer of dihydrocapsaicin, reciprocal effects were nonsignificant (Table 1). Parents vs. crosses were also statistically significant for all capsaicinoids except for nornordihydrocapsaicin and nordihydrocapsaicin (Table 1). The hybrids of NMCA80058 x NMCA80049 and NMCA80062 x NMCA80058, produced the only instances in which the quantities of the isomer of dihydrocapsaicin differed significantly than their reciprocals (data not presented).

Differences in capsaicinoid contents were significant among parents (Table 2). The parents with high capsaicinoid content also had positive and significant general combining 
Table 1. Mean squares from the diallel analysis for general combining ability (GCA), specific combining ability (SCA), and reciprocal effects for nornornordihydrocapsaicin (3-ND), nornordihydrocapsaicin ( 2-ND), nordihydrocapsaicin (NDH ), capsaicin (CAP), dihydrocapsaicin (DH), isomer of dihydrocapsaicin (ISO), homodihydrocapsaicin (HD), and total capsaicinoids (CAPSD) in five chile genotypes and their hybrids.

\begin{tabular}{|c|c|c|c|c|c|c|c|c|c|}
\hline \multirow[b]{2}{*}{ Source } & \multicolumn{8}{|c|}{ Mean squares } & \multirow[b]{2}{*}{ CAPSD } \\
\hline & df & $3-N D$ & 2-ND & $\mathrm{NDH}$ & CAP & DH & ISO & HD & \\
\hline Treatments & 24 & $* *$ & $* *$ & $* *$ & $* *$ & $* *$ & $* *$ & ** & $* *$ \\
\hline Parents vs. crosses & 1 & $* *$ & NS & NS & $* *$ & $*$ & $* *$ & ** & $* *$ \\
\hline SCA & 10 & $1471^{* *}$ & $4810^{* *}$ & $58730^{* *}$ & $625383^{* *}$ & $492796^{* *}$ & $10701^{* *}$ & $3455^{* *}$ & $2203749^{* *}$ \\
\hline Reciprocal & 10 & $94^{\mathrm{Ns}}$ & $728^{\mathrm{Ns}}$ & $14627^{\mathrm{Ns}}$ & $57665^{\mathrm{Ns}}$ & $54364^{\mathrm{Ns}}$ & $1129^{* *}$ & $322^{\mathrm{Ns}}$ & $366744^{\mathrm{Ns}}$ \\
\hline Error & 72 & 120 & 535 & 9820 & 50689 & 59474 & 347 & 191 & 326903 \\
\hline
\end{tabular}

ability effect. The correlation values between parental mean and GCA effect were positive and highly significant $\left(r=0.96^{* *}, 0.97 * *\right.$ $0.98^{* *}, 0.81,0.94 * *, 0.96^{* *}, 0.98^{* *}$, and $0.95 * *$ for 3-ND, 2-ND, NDH, CAP, DH, ISO, HD, and CAPSD, respectively). Except for the isomer of dihydrocapsaicin and the homodihydrocapsaicin, NMCA80049 and NMCA80062 had higher positive general combining ability values for all capsaicinoids than any other parent investigated. NMCA80058 was unique in having high mean and high positive general combining ability values for the isomer of dihydrocapsaicin and homodihydrocapsaicin.

There were significant differences between the means of the hybrids for all capsaicinoids (Table 3). None of the hybrids had high concentration of all the capsaicinoids. A hybrid produced from NMCA80049 $\times$ NMCA80062, two high capsaicinoid content parents, had the highest mean of the genotypes for nornordihydrocapsaicin, nordihydrocapsaicin, and total capsaicinoids. A hybrid between low and high capsaicinoid content parents (NMCA80004 X NMCA80062) had a higher mean of the genotypes for nornornordihydrocapsaicin and dihydrocapsaicin content than the hybrid from NMCA80049 x NMCA80062, high capsaicinoid content parents.

Significant negative and positive specific combining ability effects were observed among the hybrids (Table 3). A hybrid from high capsaicinoid content parents (NMCA80049 x
NMCA80062) had a positive specific combining ability value for nornordihydrocapsaicin, nordihydrocapsaicin, and the isomer of dihydrocapsaicin.

Positive and negative heterosis were also observed for the hybrids (Table 3 ). The values of high parent heterosis range between $-84 \%$ to $153 \%$. Interestingly, a hybrid from low capsaicinoid content parents, NMCA80004 x NMCA80058, had the highest high parent heterosis, $153 \%$, for capsaicin.

\section{Discussion}

Lack of significant differences for reciprocal effects for most of the compounds implies that a maternal effect for capsaicinoid inheritance in the $C$. pubescens population studied is not important. Similar results were reported for total capsaicinoids in $C$. annuum crosses (Ohta, 1962). The importance of additive and nonadditive gene effects in capsaicinoid inheritance was demonstrated by significant effects of general combining ability and specific combining ability. The association (positive correlation) of high capsaicinoid contents with high positive general combining ability of the parents also indicates the predominance of additive gene action in capsaicinoid inheritance. The relative contribution of individual parents to improve the specific trait in the population can be estimated by comparing the general combining ability effects (Lippert, 1975). Therefore, in this study parents with positive and high general combining ability have the capability for increasing the capsaicinoid content in the population. Conversely, parents with negative general combining ability effects contribute most to the reduction of capsaicinoid content.

For $F_{1}$ hybrid cultivar development, it is necessary to evaluate specific parental combinations. Negative specific combining ability indicates unfavorable combinations of parents. In this study $F_{1}$ hybrid between high capsaicinoid content parents was not the best because of its negative specific combining ability for most (four out of seven) of the capsaicinoids (Table 3). Besides this, none of the individual capsaicinoids in this hybrid were superior in quantity to those of the parents.

The significant difference of parents vs. crosses for most of the capsaicinoids (Table 1) implies the presence of average heterosis. In general, to develop a highly pungent commercial $F_{1}$ hybrid chile, the hybrid should have a capsaicinoid content greater than that of the highly pungent parent (high parent heterosis). Therefore, for practical reasons high parent heterosis was highly important in hybrid development. The best high parent heterosis in this study was observed from a hybridization between two low capsaicinoid content parents. Such results suggest that nonadditive gene action (epistasis) is also important in maximizing the capsaicinoid content of a hybrid.

Table 2. Mean capsaicinoid content ${ }^{2}$ and general combining ability (GCA) effects of the five chile genotypes for nornornordihydrocapsaicin (3-ND), nornordihydrocapsaicin (2-ND), nordihydrocapsaicin (NDH), capsaicin (CAP) dihydrocapsaicin (DH), isomer of dihydrocapsaicin (ISO), homodihydrocapsaicin (HD), and total capsaicinoids (CAPSD).

\begin{tabular}{|c|c|c|c|c|c|c|c|c|}
\hline \multirow[b]{2}{*}{ Parents } & \multicolumn{2}{|c|}{$3-N D$} & \multicolumn{2}{|c|}{$2-\mathrm{ND}$} & \multicolumn{2}{|c|}{$\mathrm{NDH}$} & \multicolumn{2}{|c|}{ CAP } \\
\hline & $\begin{array}{c}\text { Mean } \\
\left(\mathrm{mg} \cdot \mathrm{kg}^{-1}\right)\end{array}$ & GCA & $\begin{array}{c}\text { Mean } \\
\left(\mathrm{mg} \cdot \mathrm{kg}^{-1}\right)\end{array}$ & GCA & $\begin{array}{c}\text { Mean } \\
\left(\mathrm{mg} \cdot \mathrm{kg}^{-1}\right)\end{array}$ & GCA & $\begin{array}{c}\text { Mean } \\
\left(\mathrm{mg} \cdot \mathrm{kg}^{-1}\right)\end{array}$ & GCA \\
\hline NMCA80004 (low) & $24 \mathrm{c}^{\mathrm{y}}$ & 0 & $44 \mathrm{~d}^{\mathrm{y}}$ & $-36^{* *}$ & $344 \mathrm{~b}^{\mathrm{y}}$ & $-94^{* * *}$ & $428 \mathrm{c}^{\mathrm{y}}$ & $-176^{* * *}$ \\
\hline NMCA80058 (low) & $3 \mathrm{c}$ & $-21^{* *}$ & $47 \mathrm{~cd}$ & $-34^{* *}$ & $129 \mathrm{c}$ & $-161^{* *}$ & $121 \mathrm{~d}$ & $-96^{* *}$ \\
\hline NMCA80065 (low) & $10 \mathrm{c}$ & $-15^{* *}$ & $76 \mathrm{c}$ & $-18^{* * *}$ & $307 \mathrm{~b}$ & $-163^{* *}$ & $632 \mathrm{bc}$ & $-144^{* *}$ \\
\hline NMCA80049 (high) & $79 \mathrm{~b}$ & $12^{* *}$ & $148 \mathrm{~b}$ & $29^{\text {*** }}$ & $1118 \mathrm{a}$ & $182^{* *}$ & $1507 \mathrm{a}$ & $241^{* *}$ \\
\hline \multirow[t]{2}{*}{ NMCA80062 (high) } & $117 \mathrm{a}$ & $24^{* *}$ & 289 a & $60^{* *}$ & $1051 \mathrm{a}$ & $237^{* *}$ & $795 \mathrm{~b}$ & $175^{* *}$ \\
\hline & \multicolumn{2}{|c|}{$\mathrm{DH}$} & \multicolumn{2}{|c|}{ ISO } & \multicolumn{2}{|c|}{ HD } & \multicolumn{2}{|c|}{ CAPSD } \\
\hline Parents & $\begin{array}{c}\text { Mean } \\
\left(\mathrm{mg} \cdot \mathrm{kg}^{-1}\right)\end{array}$ & GCA & $\begin{array}{c}\text { Mean } \\
\left(\mathrm{mg} \cdot \mathrm{kg}^{-1}\right)\end{array}$ & GCA & $\begin{array}{c}\text { Mean } \\
\left(\mathrm{mg} \cdot \mathrm{kg}^{-1}\right)\end{array}$ & GCA & $\begin{array}{c}\text { Mean } \\
\left(\mathrm{mg} \cdot \mathrm{kg}^{-1}\right)\end{array}$ & GCA \\
\hline NMCA80004 (low) & $867 c^{y}$ & 2 & $26 \mathrm{~d}^{\mathrm{y}}$ & $-46^{* *}$ & $25 \mathrm{c}^{\mathrm{y}}$ & $-25^{* *}$ & $1758 \mathrm{c}^{\mathrm{y}}$ & $-375^{* *}$ \\
\hline NMCA80058 (low) & $180 \mathrm{~d}$ & $-426^{* *}$ & $356 \mathrm{a}$ & $68^{* *}$ & $166 \mathrm{a}$ & $67^{* *}$ & $1003 \mathrm{c}$ & $-606^{* *}$ \\
\hline NMCA80065 (low) & $481 \mathrm{~d}$ & $-399^{* *}$ & $39 \mathrm{~cd}$ & $-34^{* *}$ & $42 \mathrm{~b}$ & $-29^{* *}$ & $1587 \mathrm{c}$ & $-802^{* *}$ \\
\hline NMCA80049 (high) & $2470 \mathrm{a}$ & $363^{* * *}$ & $78 \mathrm{c}$ & 3 & $50 \mathrm{~b}$ & -3 & 5451 a & $826^{* *}$ \\
\hline NMCA80062 (high) & $1958 \mathrm{~b}$ & $460^{* *}$ & $131 \mathrm{~b}$ & $10^{* *}$ & $46 \mathrm{~b}$ & $-9^{* *}$ & $4388 \mathrm{~b}$ & $958^{* *}$ \\
\hline
\end{tabular}

z) Capsaicinoid content of the parents.

yMeans in a column followed by the same letter are not statistically different at $5 \%$ level according to Duncan's new multiple tange test.

** Significant at $P<0.01$. 
Table 3. Mean capsaicinoid content, specific combining ability (SCA), and high parent heterosis (H) for nornornordihydrocapsaicin (3-ND), nornordihydrocapsaicin (2-ND), nordihydrocapsaicin (NDH), capsaicin (CAP), dihydrocapsaicin (DH), isomer of dihydrocapsaicin (ISO), homodihydrocapsaicin (HD), and total capsaicinoids (CAPSD) of the hybrids.

\begin{tabular}{|c|c|c|c|c|c|c|c|c|c|c|c|c|}
\hline \multirow[b]{2}{*}{ Hybrid ${ }^{y}$} & \multicolumn{3}{|c|}{ 3-ND } & \multicolumn{3}{|c|}{$2-N D$} & \multicolumn{3}{|c|}{$\mathrm{NDH}$} & \multicolumn{3}{|c|}{ CAP } \\
\hline & $\begin{array}{c}\text { Mean }^{2} \\
\left(\mathrm{mg} \cdot \mathrm{kg}^{-1}\right)\end{array}$ & SCA & $\mathrm{H}(\%)$ & $\begin{array}{c}\text { Mean }^{2} \\
\left(\mathrm{mg} \cdot \mathrm{kg}^{-1}\right)\end{array}$ & SCA & $\mathrm{H}(\%)$ & $\begin{array}{c}\text { Mean }^{2} \\
\left(\mathrm{mg} \cdot \mathrm{kg}^{-1}\right)\end{array}$ & SCA & $\mathrm{H}(\%)$ & $\begin{array}{c}\text { Mean }^{z} \\
\left(\mathrm{mg} \cdot \mathrm{kg}^{-1}\right)\end{array}$ & SCA & $\mathrm{H}(\%)$ \\
\hline $\mathrm{P}_{1} \times \mathrm{P}_{2}$ & $43 c^{x}$ & -4 & -46 & $92 \mathrm{de}^{\mathrm{x}}$ & $-16^{*}$ & -38 & $565 \mathrm{~cd}^{\mathrm{x}}$ & $-125^{* *}$ & -49 & $872 \mathrm{~cd}^{\mathrm{x}}$ & $-197^{* *}$ & -42 \\
\hline $\mathrm{P}_{1} \times \mathrm{P}_{3}$ & $17 \mathrm{f}$ & 4 & -29 & $63 \mathrm{fg}$ & $19^{* *}$ & 34 & $488 \mathrm{~d}$ & $148^{* *}$ & 42 & $1083 \mathrm{bc}$ & $368^{* *}$ & 153 \\
\hline $\mathrm{P}_{1} \times \mathrm{P}_{4}$ & $69 a$ & $10^{* *}$ & -41 & $135 \mathrm{bc}$ & -4 & -53 & $803 \mathrm{~b}$ & $60^{*}$ & -24 & $1163 \mathrm{ab}$ & $165^{*}$ & 46 \\
\hline $\mathrm{P}_{1} \times \mathrm{P}_{5}$ & $21 \mathrm{f}$ & 1 & 3 & $58 \mathrm{~g}$ & -2 & -24 & $326 \mathrm{e}$ & -16 & -5 & 564 e & -116 & -11 \\
\hline $\mathrm{P}_{2} \times \mathrm{P}_{3}$ & 22 ef & -4 & -72 & $112 \mathrm{~cd}$ & 2 & -24 & $582 \mathrm{~cd}$ & -42 & -48 & $1232 \mathrm{ab}$ & 77 & -18 \\
\hline $\mathrm{P}_{2} \times \mathrm{P}_{4}$ & $55 \mathrm{~b}$ & $-14^{* *}$ & -53 & $221 \mathrm{a}$ & $20^{* *}$ & -24 & $1020 \mathrm{a}$ & 11 & -9 & $1341 \mathrm{ab}$ & -51 & -11 \\
\hline $\mathrm{P}_{2} \times \mathrm{P}_{5}$ & $34 \mathrm{~cd}$ & 1 & -57 & $151 \mathrm{~b}$ & $18^{*}$ & 2 & $641 \mathrm{c}$ & 1 & -43 & $1259 \mathrm{ab}$ & $145^{*}$ & -16 \\
\hline $\mathrm{P}_{3} \times \mathrm{P}_{4}$ & $19 \mathrm{f}$ & $-18^{* *}$ & -84 & $98 \mathrm{de}$ & $-41^{* *}$ & -66 & $679 \mathrm{c}$ & 7 & -35 & $1383 \mathrm{a}$ & $315^{* *}$ & 74 \\
\hline $\mathrm{P}_{3} \times \mathrm{P}_{5}$ & $6 \mathrm{~g}$ & $7^{*}$ & -40 & 85 ef & $18^{*}$ & 12 & $325 \mathrm{e}$ & 35 & 6 & $702 \mathrm{de}$ & -78 & 11 \\
\hline \multirow[t]{2}{*}{$\mathrm{P}_{4} \times \mathrm{P}_{5}$} & $30 \mathrm{de}$ & $-13^{* *}$ & -74 & $128 \mathrm{bc}$ & $-30^{* *}$ & -55 & $625 \mathrm{c}$ & -54 & -41 & $1161 \mathrm{ab}$ & 126 & 46 \\
\hline & \multicolumn{3}{|c|}{$\mathrm{DH}$} & \multicolumn{3}{|c|}{ ISO } & \multicolumn{3}{|c|}{ HD } & \multicolumn{3}{|c|}{ CAPSD } \\
\hline Hybrid $^{y}$ & $\begin{array}{c}\text { Mean }^{z} \\
\left(\mathrm{mg} \cdot \mathrm{kg}^{-1}\right)\end{array}$ & SCA & $\mathrm{H}(\%)$ & $\begin{array}{c}\text { Mean }^{2} \\
\left(\mathrm{mg} \cdot \mathrm{kg}^{-1}\right)\end{array}$ & SCA & $\mathrm{H}(\%)$ & $\begin{array}{c}\text { Mean }^{\mathrm{z}} \\
\left(\mathrm{mg} \cdot \mathrm{kg}^{-1}\right)\end{array}$ & SCA & $\mathrm{H}(\%)$ & $\begin{array}{c}\text { Mean }^{z} \\
\left(\mathrm{mg} \cdot \mathrm{kg}^{-1}\right)\end{array}$ & SCA & $\mathrm{H}(\%)$ \\
\hline $\mathrm{P}_{1} \times \mathrm{P}_{2}$ & $1476 c^{x}$ & $-187^{* * *}$ & -40 & $59 \mathrm{de}^{\mathrm{x}}$ & 5 & -24 & $38 \mathrm{fg}^{\mathrm{x}}$ & $-8^{*}$ & -24 & $3144 c^{x}$ & $-531^{* *}$ & -42 \\
\hline $\mathrm{P}_{1} \times \mathrm{P}_{3}$ & $1157 \mathrm{~d}$ & $292^{* *}$ & 33 & $76 \mathrm{~d}$ & $-42^{* *}$ & -79 & $122 \mathrm{c}$ & 7 & -26 & $3006 \mathrm{c}$ & $796^{* *}$ & 71 \\
\hline $\mathrm{P}_{1} \times \mathrm{P}_{4}$ & $2170 \mathrm{a}$ & $411^{* *}$ & 11 & $66 \mathrm{de}$ & 4 & -50 & $36 \mathrm{fg}$ & -4 & -22 & $4441 \mathrm{a}$ & $642^{* *}$ & 1 \\
\hline$P_{1} \times P_{5}^{4}$ & 817 e & -82 & -6 & $30 \mathrm{f}$ & $13^{*}$ & -23 & $25 \mathrm{~g}$ & 5 & -40 & $1841 \mathrm{~d}$ & -199 & 5 \\
\hline $\mathrm{P}_{2} \times \mathrm{P}_{3}$ & $1158 \mathrm{~d}$ & -83 & -53 & $159 \mathrm{a}$ & -10 & -55 & $173 \mathrm{a}$ & $35^{* *}$ & 4 & $3438 \mathrm{bc}$ & -24 & -37 \\
\hline $\mathrm{P}_{2} \times \mathrm{P}_{4}$ & $1879 \mathrm{~b}$ & $-217^{* *}$ & -24 & $129 \mathrm{~b}$ & $19^{* *}$ & -2 & $52 \mathrm{e}$ & $-9^{*}$ & 4 & $4698 \mathrm{a}$ & -240 & -13 \\
\hline $\mathrm{P}_{2} \times \mathrm{P}_{5}$ & $1315 \mathrm{~cd}$ & 38 & -47 & $82 \mathrm{~d}$ & $11^{*}$ & 5 & 43 ef & -1 & -14 & $3525 \mathrm{bc}$ & 213 & -35 \\
\hline $\mathrm{P}_{3} \times \mathrm{P}_{4}$ & $1361 \mathrm{~cd}$ & 29 & -30 & $137 \mathrm{~b}$ & $-39^{* *}$ & -62 & $157 \mathrm{~b}$ & $26^{* *}$ & -5 & $3835 \mathrm{~b}$ & 280 & -13 \\
\hline $\mathrm{P}_{3} \times \mathrm{P}_{5}$ & $510 \mathrm{f}$ & 26 & 6 & $103 \mathrm{c}$ & $-33^{* *}$ & -72 & $87 \mathrm{~d}$ & $-28^{* * *}$ & -48 & $1818 \mathrm{~d}$ & -51 & 15 \\
\hline $\mathrm{P}_{4} \times \mathrm{P}_{5}$ & $1397 \mathrm{~cd}$ & 36 & -29 & $76 \mathrm{~d}$ & 1 & -42 & $32 \mathrm{fg}$ & -3 & -30 & 3449 bc & 62 & -21 \\
\hline
\end{tabular}

${ }^{\mathrm{z}}$ Average of the reciprocal hybrids.

${ }^{y}$ Hybrids of $\mathrm{P}_{1}=$ NMCA80004 (low capsaicinoid); $\mathrm{P}_{2}=$ NMCA80049 (high capsaicinoid); $\mathrm{P}_{3}=$ NMCA80058

(low capsaicinoid); $\mathrm{P}_{4}=$ NMCA80062 (high capsaicinoid); and $\mathrm{P}_{5}=$ NMCA80065 (low capsaicinoid), respectively.

${ }^{x}$ Means in a column followed by the same letter are not statistically different at $5 \%$ level according to Duncan's new multiple range test.

*,** Significant at $P<0.05$ and 0.01 , respectively.

Due to the predominance of additive gene action in capsaicinoid inheritance, recurrent selection, a breeding method that increases the frequency of favorable alleles and identifies the superior combinations by repeated crossing and selection could be the best method to exploit the additive gene effects in this population. The presence of high parent heterosis suggests an additional opportunity for developing $F_{1}$ hybrid chiles with high pungency.

\section{Literature Cited}

Bosland, P.W. 1993. Breeding for quality in Capsicum. Capsicum and Eggplant Nswl. 12:25-31.

Bosland, P.W. 1996. Capsicums: Innovative uses of an ancient crop, p. 479-487. In: J. Janick (ed.). Progress in new crops. ASHS Press, Alexandria, Va.
Bosland, P.W. and E.J. Votava. 1999. Peppers: Vegetable and spice capsicums. CABI Publishing, Wallingford, UK.

Burow, M.D. and J.G. Coors. 1994. Diallel: A microcomputer program for the simulation and analysis of diallel crosses. Agron. J. 86:154158.

Collins, M., L.M. Wasmund, and P.W. Bosland. 1995. Improved method for quantifying capsaicinoids in Capsicum using high-performance liquid chromatography. HortScience 30:137-139.

Collins, M. and P. Bosland. 1994. Rare and novel capsaicinoid profiles in Capsicum. Capsicum and Eggplant Nswl. 13:48-51.

Griffing, B. 1956. Concept of general and specific combining ability in relation to diallel crossing systems. Aust. J. Biol. Sci. 9:463-493.

Hallaur, A.R. and J.B. Miranda. 1981. Quantitative genetics in maize breeding. Iowa State Univ. Press, Ames.
Krajewska, A.M. and J.J. Powers. 1988. Sensory properties of naturally occurring capsaicinoids. J. Food Sci. 53:902-905.

Lippert, L. F. 1975. Heterosis and combining ability in chili peppers by diallel analysis. Crop Sci. 15:323-325.

Ohta, Y. 1962. Physiological and genetical studies on the pungency of Capsicum, V. inheritance of pungency. Jpn. J. Genet. 37:169-175.

SAS Inst., Inc. 1999. SAS software release 8.0. SAS Inst., Cary, N.C.

Suzuki, T. and K. Iwai. 1984. Constituents of red pepper species: Chemistry, biochemistry, pharmacology, and food science of the pungent principle of Capsicum species, p. 227-299. In: A. Brossi (ed.) The alkaloids: Chemistry and pharmacology. Vol. 23 Academic Press, Orlando, Fla.

Torabi, H. 1997. Identification of novel capsaicinoids. M.S. Thesis, New Mexico State Univ., Las Cruces. 